Schönborn, G., Berlin, C., Pinzone, M., Hanisch, C., Georgoulias, K., \& Lanz, M. (2019). Why social sustainability counts: The impact of corporate social sustainability culture on financial success. Sustainable Production and Consumption, 17, 1-10.

https://doi.org/10.1016/j.spc.2018.08.008

\title{
Why Social Sustainability Counts: The Impact of Corporate Social Sustainability Culture on Financial Success
}

\author{
Gregor Schönborn ${ }^{1}$, Cecilia Berlin*2, Marta Pinzone ${ }^{3}$, Christoph Hanisch ${ }^{4}$, Konstantinos \\ Georgoulias $^{5}$, Minna Lanz ${ }^{6}$
}

\author{
AFFILIATIONS \\ ${ }^{1}$ Deep White Research, Kurt-Schumacher-Str. 2, 53113 Bonn, Germany \\ ${ }^{2}$ Chalmers University of Technology, Department of Industrial and Materials Science, Division of \\ Production Systems, Hörsalsvägen 7A, SE-41296 Göteborg, Sweden \\ ${ }^{3}$ Politecnico di Milano, Department of Management, Economics and Industrial Engineering, Via \\ Lambruschini, 4/B, 20156 Milano, Italy \\ ${ }^{4}$ Festo AG \& Co. KG, Ruiter Str. 82, 73734 Esslingen/Berkheim, Germany \\ ${ }^{5}$ Laboratory for Manufacturing Systems \& Automation, Department of Mechanical Engineering and \\ Aeronautics, University of Patras, Rio, Patras 26500, Greece \\ ${ }^{6}$ Tampere University of Technology, Korkeakoulunkatu 10, 33720 Tampere, Finland \\ * Corresponding author, cecilia.berlin@,chalmers.se, +46317721290
}

\begin{abstract}
Awareness is growing in European companies of the importance of managing all aspects of sustainability. However, the elusive social aspect of sustainability and its influence on successful business has been under-investigated in corporate culture literature so far. The aim of this paper is to examine whether a correlation can be found between corporate social sustainability culture (expressed as explicit "items" of corporate values and practices emphasizing employee and societal well-being) and the financial success of a company. This is examined through a multiple regression analysis of two contrasting European polls, examining items indicating corporate social sustainability culture, and financial outcomes. The empirical results show that four specific success-related social sustainability
\end{abstract}


dimensions of corporate culture are predictors of a company being classified as financially successful. These are: Sustainability strategy and leadership; Mission, communication and learning; Social care and work life; and Loyalty and identification. The paper contributes to the understanding of how to manage corporate social sustainability culture whilst supporting companies' financial performance, and provides evidence-grounded recommendations to business managers and stakeholders aiming to manage social sustainability proactively by undertaking cultural change and development initiatives.

\section{Keywords}

sustainability, social sustainability, corporate culture, corporate sustainability, financial performance, success factors

\section{Introduction}

A growing ageing population, changing labour markets, evolving patterns of migration and urbanization, rapid technological progress in automation and information technologies and other societal, economic and technological mega-trends are now transforming human work and life and business environments, putting companies under strong pressure to change radically the way in which they operate (Calvano, 2013; Chand \& Tung, 2014; George et al., 2014; Kulik et al., 2014). A parallel growing interest in the social performance of companies (Schrempf-Stirling et al., 2015) indicates that it is no longer viable to unsustainably exploit human and social resources and ignore the needs of stakeholders inside and outside the company (Pfeffer, 2010).

Considering this, managing social sustainability - which is conceptualized in this study as the social component of employees and society that is impacted by and has an impact on business practices - is gaining importance in politics, society and the economy as a fundamental approach for dealing with the global challenges of the future (Sachs, 2012). Customers, business partners, analysts and - last but not least - potential employees are increasingly asking for activities and measurable parameters with respect to social sustainability (Schönborn, 2014). Management now increasingly pay attention to how companies can align the requirements of social sustainability with those of competitiveness (Destatis, 
2014; Epstein \& Buhovac, 2014; Hollensbe et al., 2014; Husted \& Allen, 2011; Porter \& Kramer, 2011).

Research contributions focused on Corporate Social Responsibility (CSR) and sustainability have consistently claimed that companies need to change their corporate culture to enable an integrated approach to social and economic issues (Calabrese et al., 2013; Maon, et al., 2010; Sean \& Saliba, 2016).

However, many researchers (e.g. Barker et al., 2014; Docherty et al., 2008; Linnenluecke \& Griffiths, 2010) have pointed out a need for greater conceptual development regarding the characteristics of corporate social sustainability (CSS) culture. Furthermore, the literature (e.g. Galbreath, 2010; Pfeffer, 2010) has highlighted a dearth of empirical evidence regarding the relationship between CSS culture and corporate success. These knowledge gaps mean that so far, most companies have not managed to tackle social sustainability proactively but have considered it an ad hoc measure or an add-on to core business (Kiron et al., 2013), due to a lack of recommendations about how CSS culture can bring about long-term competitive advantages and superior performance (Schönborn, 2014).

The present study aims at narrowing the aforementioned knowledge gaps, by hypothesizing and examining whether there is a positive correlation between CSS culture and the financial success of a company. Based on previous contributions from Corporate Social Responsibility (CSR) and social sustainability literature (e.g., Maon et al., 2010; Wood, 2010; Epstein \& Buhovac, 2014) as well as culture-effectiveness literature (e.g. Sackmann, 2011; Boyce et al., 2015), we identified relevant dimensions of CSS culture and developed a set of hypotheses on their positive relationship with company success, which were then tested on the primary data collected for this study.

The data for the study was collected in the context of the EU project SO SMART (Socially sustainable manufacturing for the Factories of the Future; see Berlin et al., 2016). The project context enabled the authors to collect primary data from European countries through recruitment opportunities and voluntary participation among the project's extended manufacturing-related networks.

By taking this unique opportunity to collect primary data from the field, our results contribute to expand previous knowledge by highlighting four specific success-related social sustainability aspects of corporate culture that are strongly linked with companies' economic success. 
Our study contributes insights relevant to business managers and stakeholders who are willing to undertake culture change and development initiatives, aimed at managing social sustainability proactively and supporting companies' performance at the same time.

The paper proceeds as follows: first, relevant literature is presented that informs our study, and the development of the study's hypotheses. Second, the analytical methodology is described. Third, the results are presented and discussed from theoretical and managerial perspectives. Finally, we indicate limitations and avenues for future research.

\section{Theoretical background and development of hypotheses}

\subsection{Social Sustainability and Corporate Culture}

The overall social development, which meets the needs of both present and future generations, is generally known to the public as "sustainable" and is acknowledged as a necessity in all strata of society (Sachs, 2012). Spangenberg and Omann (2006) propose a system dynamics concept of social sustainability, writing that it is a qualitative criterion that requires multi-criteria assessment to be fairly captured in economy, society and population (in a European, and particularly a German, policy context). Their work suggested the following criteria for social sustainability: self-determined life and mixed work; satisfaction of basic needs; reliable and sufficient security system; equal opportunities, participation, democracy; social innovations; intergenerational equity; objective and subjective basic needs; objective and subjective social resources; objective and subjective equal opportunities; subjective participation; objective sustaining oneself; cultural diversity; and solidarity and tolerance. As evidenced by the crosscutting nature of these criteria, all societal strata are touched upon.

Awareness of social sustainability-oriented practices (e.g., Longoni, \& Cagliano, 2015) and reporting methods (e.g., Searcy et al., 2016) has increased in companies during last years. It seems that companies are starting to shift from a purely profit-driven to a triple-bottom-line approach (Elkington, 1997) and to address the challenges and opportunities of sustainable company management (Lee \& Kim, 2017). In this respect, previous studies argue that corporate culture plays an essential role (e.g., 
Galbreath, 2010), as it determines the degree to which business is conducted responsibly or irresponsibly (Barker et al., 2014.).

Corporate culture has been defined in a wide variety of ways during last decades (Sackmann, 2011). One of the most widely accepted conceptualization states that corporate culture consists of artefacts, values and basic assumptions (Schein 1984, 1990, 2009). Artefacts are visible organizational structures and processes - what employees see, hear, and feel when go into an organization; values refer to what is right for means and ends; and basic assumptions are unconscious taken for granted beliefs. This three-level model of corporate culture of Schein (2009) is understood as a supplement by Hatch (2011) as a dynamic interaction of the levels. Hatch (2011) presented corporate culture as a dynamic model where there is a mutual influence between corporate culture and the identity of the company. The meaning of the basic assumptions is identifiable in the collective values and would influence behaviour and conduct. A part of the behaviour or conduct would consolidate visibly and thus stabilize the culture. The interpretation by the members of the organization with respect to the basic assumptions demonstrates the interaction between the levels, and it can shape or even change the culture over time.

Within the CSR and sustainability literature, changing the corporate culture has been consistently acknowledged as crucial to go beyond a superficial stance (Linnenluecke \& Griffiths, 2010) and enable a substantive, integrated approach to the social and economic issues affecting stakeholders (Calabrese et al., 2013; Maon et al., 2010; Sean \& Saliba, 2016; Weerts et al., 2018). In this regard, Jones et al. (2007) proposed a continuum of five stakeholder cultures ranging from "agency culture", in which there is no concern for others, to "altruistic culture", which is based on concern for the interests of all stakeholders. Similarly, Maon et al. (2010) presented a three-stage model of culture development, ranging from a "cultural reluctance phase", where the company is mainly self-interested, to a "cultural embedment phase", where the company recognises social issues as potential opportunities for new value creation.

Consequently, the authors of the present study assume that social sustainability is expressed in the corporate culture, and we conceptualize Corporate Social Sustainability (CSS) culture as a corporate 
culture characterized by artefacts, values and basic assumptions underpinned by the notion, scope and principles of social sustainability. Within CSS culture, strategies, policies, and management systems ensure that social considerations are addressed alongside economic ones throughout the company (Marshall et al., 2015). Values, norms and mind-sets are aligned to social sustainability goals and guide organizational actors' decision-making and behaviours at all organizational levels (Duarte, 2010; Eccles et al., 2012). CSS culture is, thus, conceived as multi-dimensional and encompassing the values, beliefs, norms and practices that facilitate, give direction, and reinforce relations between the company and its (internal and external) stakeholders, to harmonize these bi-directional relationships and improve triple-bottom-line performance. Epstein et al.'s (2015) case studies on companies with leading practices in management of sustainability found that in such "best-in-class" companies, decisions are made based on organizational values that support long-term reasoning and decisionmaking; there is awareness of anticipated stakeholder reactions to corporate social/environmental performance; and creative use of technology and innovation occurs to overcome trade-offs among sustainability and economic goals.

\subsection{Corporate Social Sustainability Culture and Corporate success}

During past decades, numerous studies have investigated the relationship between corporate culture and corporate success (Hatch, 2011; Sackmann, 2002, 2007, 2011; Sackmann \& Stiftung, 2006; Schein, 2010; Denison et al., 2014). According to the Resource-based view, cultures that are valuable, rare, and not easily replicated can facilitate superior performance (Boyce et al., 2015). Indeed, the authors of the present study argue that companies with CSS culture are expected to achieve competitive advantage by substantively reducing costs or generating benefits, both of which improve financial performance. In this respect, the explorative study by Schönborn (2010) highlighted that corporate responsibility, with respect to employees as well as external stakeholders, accompanied by participative leadership, are crucial cultural conditions for corporate success.

Accordingly, companies with CSS culture can create socially sustainable working environments (Docherty et al., 2008), which have positive effects on employees (Glavas, 2016) - such as higher job satisfaction, meaningful work and sense of belonging - with a consequent improvement in employee 
performance and reduction in costs related to absenteeism and staff voluntary turnover (Pinzone et al., 2018). Moreover, providing managers and employees with continuous learning opportunities, they can develop a superior human capital with positive effects on performance in terms of productivity, quality and innovation (Pinzone et al., 2018).

Additionally, companies with CSS culture can identify and take advantage of new business opportunities (Porter \& Kramer, 2011). The integration social sustainability in the strategic processes, communication and collaboration with stakeholders increase the capacity of companies with a CSS culture to understand the context in which they operate and its future evolution (Baumgartner, 2014). They can therefore develop and execute proactive sustainability strategies to continuously improve the existing processes and products/services (Baumgartner, 2014; Schaltegger \& Burritt, 2018). Leveraging on new forms of collaboration with stakeholders, they can also go further in changing the competitive scenario through socially sustainable innovations in terms of new products/services, business models and markets (Schaltegger \& Burritt, 2018), which result in new revenue streams and/or increasing margins.

Finally, CSS culture can facilitate the creation of value by enhancing the perception among key stakeholders that the company is authentically "doing good" (Perrini et al., 2011). This can increase its attractiveness as employers (Jones et al., 2014), build legitimacy and trust in the stakeholder network (Eccles et al., 2012), enhance brand value and reputation (Orlitzky et al., 2003), and positive evaluation by investors (Lo \& Kwan, 2017; Schaltegger \& Burritt, 2018).

\subsection{Development of Hypotheses}

Based on the aforementioned literature, we hypothesize for the present study that a positive relationship exists between CSS culture and corporate success (HO). Specifically, the following hypotheses, which are adapted from earlier work on success-related corporate culture by Schönborn (2014), are elaborated and then tested empirically in relation to CSS culture items. They sequentially form prerequisites for each other, and underpin the present investigation, as follows: 
Hypothesis $O(H 0)$. The system of values created by a company, and followed by its employees, especially values of social sustainability, is positively correlated with the success of the company.

First, it is assumed that the orientation of values in successful companies, in general, is more pronounced in their corporate culture, than in less successful companies:

Hypothesis 1 (H1). The numerical mean of the value profile (mean value $m v$ ) in successful companies (sc) is higher (more strongly pronounced) than in non-successful companies $(n-s c)$. I.e., $\boldsymbol{m v}(\boldsymbol{s c})>\boldsymbol{m v}(\boldsymbol{n}$-sc $)$

Moreover, dimensions found to be more intensely pronounced can in turn be identified as characteristics of a successful company:

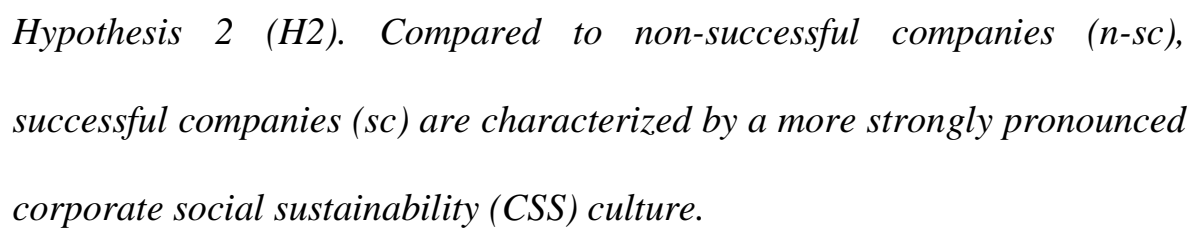

It is assumed that the characteristic features for the success (H2) of successful companies (sc), especially related to social sustainability, differ significantly from non-successful companies (n-sc):

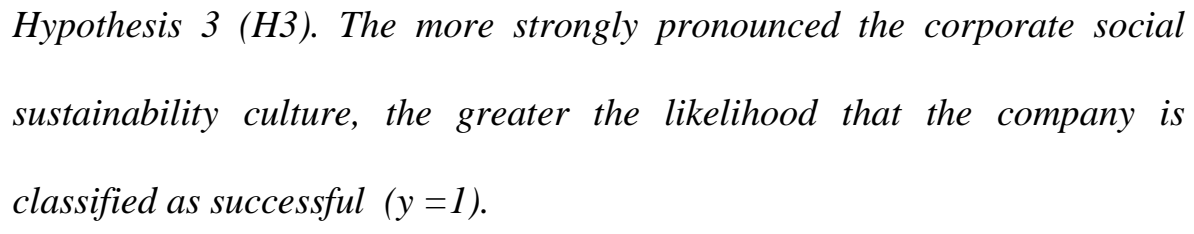

Finally, successful companies (sc) and non-successful companies (n-sc) differ from one another not only in the profile of the CSS culture overall, but there is also a correlation between the characteristics of the values' respective manifestation and the success of the company (characteristics for success). 
Hypothesis 4 (H4). The more strongly pronounced the CSS culture

characteristics for success in a company, the greater the likelihood that the company is classified in the group of successful companies $(y=1)$.

\section{Methods}

The hypotheses were tested on primary data collected from two online surveys about CSS culture and corporate success, where participants were recruited from the international networks available to the EU project SO SMART. One survey sample focused on the point of view of the company employer, while by contrast the other targeted the point of view of the individual employee. The following data were collected:

1) a survey of employees at 8 German industrial companies (referred to as "Company poll"), and

2) a pan-European individual employee panel (referred to as "Panel poll").

\subsection{Sampling}

Since participating companies for the company poll were recruited based on voluntary participation and contacted through the networks of the EU project SO SMART, a convenience sample emerged, consisting of mainly German companies. In order to avoid a "German-biased" survey claiming to represent Europe, we decided to intentionally narrow down the corporate-focused study to a purely German sample to control for influences of differing national cultures. This delimitation must be kept in mind; meanwhile, we argue that in light of Germany's considerable participation in current manufacturing developments, it is motivated to study in its own right, as one of the most advanced manufacturing countries in Europe. To contrast and validate the results from the company poll, we also collected a second, contrasting dataset on a pan-European level (using a paid professional panel recruitment service). The Panel poll yielded participants from 15 European countries, covering Northern and Southern Europe (Belgium, Denmark, Germany, Finland, France, Greece, Ireland, Italy, Netherlands, Norway, Poland, Sweden, Spain, Switzerland and United Kingdom).

The company poll consisted of 233 employee respondents from eight German companies. The collected response data were filtered so that respondents with $30 \%$ or less average completion time of 
the questionnaire and/or more than 20 omitted answers were eliminated from the data set. Altogether, these steps resulted in 207 respondents for the company poll.

\section{TABLE 1}

Company Poll Data (Germany) - data collected 2014

\begin{tabular}{lllll}
\hline Company & Area of operations & Industry & $\begin{array}{l}\text { No. of } \\
\text { employees }\end{array}$ & $\begin{array}{l}\text { Yearly } \\
\text { turn-over } \\
\text { (million EUR) }\end{array}$ \\
\hline Festo & $\begin{array}{l}\text { Automation engineering } \\
\text { and services }\end{array}$ & $\begin{array}{l}\text { Manufacturing, fabrication, } \\
\text { installation and repair }\end{array}$ & 20,000 & 2,000 \\
Hodey & Health care services & $\begin{array}{l}\text { Health services, social } \\
\text { work activities }\end{array}$ & 200 & 50 \\
Juzo & $\begin{array}{l}\text { Manufacturing of health } \\
\text { care products }\end{array}$ & $\begin{array}{l}\text { Manufacturing, fabrication, } \\
\text { installation and repair }\end{array}$ & 1,000 & 250 \\
Wittenstein & $\begin{array}{l}\text { Fabrication of mechatronic } \\
\text { and drive technologies }\end{array}$ & $\begin{array}{l}\text { Manufacturing, fabrication, } \\
\text { installation and repair }\end{array}$ & 1,000 & 250 \\
Interboden & Architecture and buildings & Construction & 200 & 50 \\
$\begin{array}{l}\text { GLS Bank } \\
\text { Miltenyi } \\
\text { Biotec }\end{array}$ & $\begin{array}{l}\text { Banking } \\
\text { Manufacturing of biotec } \\
\text { products }\end{array}$ & $\begin{array}{l}\text { Finance, banking, insurance } \\
\text { Manufacturing, fabrication, }\end{array}$ & 500 & 2,000 \\
$\begin{array}{l}\text { Altanstallation and repair } \\
\text { BYK } \\
\text { Chemie }\end{array}$ & $\begin{array}{l}\text { Manufacturing of chemical } \\
\text { additives and instruments }\end{array}$ & $\begin{array}{l}\text { Manufacturing, fabrication, } \\
\text { installation and repair }\end{array}$ & 2,000 & 1,000 \\
\hline
\end{tabular}

A respondent background data section of the survey covered: a) Sociodemographic data (individual): Sex, Age, Years of employment, Division generally/concrete, Managerial responsibility/number of subordinates, Position; b) Socioeconomic (company) data: Country, Industry sector, Turnover, and number of employees.

The total panel data initially consisted of 1163 respondents, which were reduced to 971 after eliminating respondents that i) contained more than five contiguous omitted answers, ii) spent less than $30 \%$ of the average completion time on filling in the questionnaire, iii) had many omitted answers, and/or iv) had very regular response patterns.

Thus, the final sample consisted of 971 panel poll respondents and 207 German company respondents, altogether 1178 respondents, whose sociodemographic characteristics are shown in Table 2.

TABLE 2 
Sociodemographic data: Final Sample ${ }^{1}$

\begin{tabular}{|c|c|c|c|c|c|c|}
\hline & female & male & & & & missing data \\
\hline Sex & $41.68 \%$ & $58.15 \%$ & & & & $0.17 \%$ \\
\hline \multirow[t]{2}{*}{ Age } & $<\mathbf{3 0}$ & 30-39 & $40-49$ & $50-60$ & $>60$ & \\
\hline & $19.34 \%$ & $30.20 \%$ & $28.07 \%$ & $18.49 \%$ & $3.65 \%$ & $0.25 \%$ \\
\hline \multirow{2}{*}{$\begin{array}{c}\text { Managerial } \\
\text { responsibility }\end{array}$} & yes & no & & & & \\
\hline & $48.82 \%$ & $50.88 \%$ & & & & $0.30 \%$ \\
\hline \multirow[t]{2}{*}{ If yes, no. of staff } & $<5$ & $5-10$ & $11-20$ & $21-50$ & $>\mathbf{5 0}$ & \\
\hline & $38.32 \%$ & $25.55 \%$ & $17.37 \%$ & $9.58 \%$ & $8.58 \%$ & $0.60 \%$ \\
\hline \multirow{2}{*}{$\begin{array}{l}\text { No. of years with } \\
\text { company }\end{array}$} & $<1$ & $1-2$ & $3-7$ & 8-15 & $>15$ & \\
\hline & $6.88 \%$ & $13.33 \%$ & $37.44 \%$ & $24.02 \%$ & $18.17 \%$ & $0.16 \%$ \\
\hline
\end{tabular}

${ }^{1} \mathrm{~N}=1178$

\subsection{Measures}

\subsubsection{Corporate Social Sustainability Culture}

Since currently the literature does not offer a comprehensive measure of CSS culture, we undertook a set of steps to operationalize the CSS culture construct. First, key indicators of social sustainability and manufacturing performance were identified in scientific literature, international guidelines for sustainability management, and other codified reporting norms - most notably the G4 Sustainability Reporting Guidelines (Global Reporting Initiative, 2013) and the UN Global Compact, (2014). An initial comprehensive set of 300 indicators was taken mostly from reporting standards, which employ 'Key Performance Indicators' (KPIs), indicating the extent to which a company practices a strategy for sustainability. Additional sources for the long-list of indicators were Cottyn et al. (2011), Lanz et al. (2014), Unver (2013), ISO 22400-2 (YEAR), Mejabi (2009), and Wang (2011). The gathered KPIs were first classified according to the object of analysis into 'economics', 'labor', 'human rights', 'social', 'product responsibility', 'environment' and 'technical', and further sub-classified later on. To consolidate all indicators consistently, redundancies were eliminated and indicators were qualitatively clustered into eleven categories, which make up the dimensions of corporate social sustainability culture that we examine in this study. An analysis of the interrelations and interdependencies between the identified KPIs showed that the identified indicators greatly influence economic profitability, which is a precondition for analyzing the relationship between CSS culture and company success. 
Eventually, the analyses, expert board validation and consolidation of existing indicators resulted in the set of items, grouped into dimensions, shown in Table 3.

TABLE 3

Eleven Dimensions of Socially Sustainable Corporate Culture, based on indicators from literature

\begin{tabular}{|c|c|c|}
\hline Dimension & Items & Sources of relevant indicators \\
\hline 1. Commitment & $\begin{array}{l}\text { Commitment to act in support of } \\
\text { social sustainability. } \\
>\quad \text { Fulfilling a specific standard for } \\
\text { documenting social sustainability } \\
\text { activities. } \\
>\text { Fulfilling a related programmatic act. } \\
>\text { Meeting universal conditions of } \\
\text { sustainability. }\end{array}$ & $\begin{array}{ll}\text { Global } & \text { Reporting } \\
(2013) & \end{array}$ \\
\hline $\begin{array}{l}\text { 2. Corporate Social } \\
\text { Expertise }\end{array}$ & 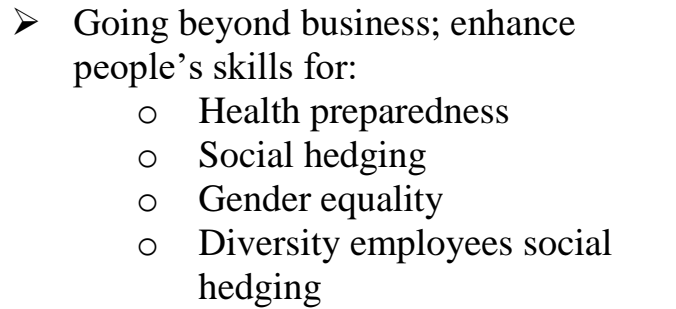 & $\begin{array}{l}\text { Global Reporting } \\
(2013)-7 \text { indicators }\end{array}$ \\
\hline 3. Clear Objectives & $\begin{array}{l}\text { Set goals for company and } \\
\text { employees. } \\
\quad \text { Identify performance indicators for } \\
\text { benchmarking systems. }\end{array}$ & $\begin{array}{l}\text { Global Reporting } \\
(2013)-2 \text { indicators }\end{array}$ \\
\hline $\begin{array}{l}\text { 4.Alliance to } \\
\text { Strategy }\end{array}$ & $\begin{array}{l}>\text { Integration into core business. } \\
>\text { Relevance according to economic } \\
\text { impact. } \\
>\text { Strategic analysis to opportunities and } \\
\text { risks. } \\
>\text { Preserve customer satisfaction. }\end{array}$ & $\begin{array}{l}\text { Global Reporting Initiative } \\
(2013)-5 \text { indicators } \\
\text { Cottyn }(2011)-1 \text { indicator }\end{array}$ \\
\hline $\begin{array}{l}\text { 5. Community } \\
\text { Contribution }\end{array}$ & $\begin{array}{l}>\text { Link to local community or region } \\
\text { community. } \\
>\text { Local suppliers involved. } \\
>\text { Employees and management from } \\
\text { local community. }\end{array}$ & $\begin{array}{l}\text { Global Reporting } \\
(2013)-6 \text { indicators }\end{array}$ \\
\hline $\begin{array}{l}\text { 6. Assume Corporate } \\
\text { Responsibility }\end{array}$ & $\begin{array}{l}\text { Take responsibility for corporate } \\
\text { activity and results; ecological } \\
\text { needs/preserve energy, water, } \\
\text { resources, biodiversity. } \\
>\text { Workers' rights/freedom to negotiate. } \\
\text { Respect for human rights/anti- } \\
\text { corruption. }\end{array}$ & $\begin{array}{l}\text { Global Reporting } \\
(2013)-9 \text { indicators }\end{array}$ \\
\hline $\begin{array}{lr}\text { 7. Rules and } \\
\text { Processes }\end{array}$ & $\begin{array}{l}\text { Specific system for achievements. } \\
\text { Involvement of employees in } \\
\text { operational changes, including } \\
\text { collective agreements. }\end{array}$ & $\begin{array}{l}\text { Global Reporting } \\
(2013)-2 \text { indicators }\end{array}$ \\
\hline
\end{tabular}




\begin{tabular}{|c|c|c|}
\hline $\begin{array}{l}\text { 8. Preserve and } \\
\text { promote } \\
\text { employability }\end{array}$ & $\begin{array}{l}>\text { Support and improve personnel skills. } \\
\text { Employees receive regular } \\
\text { performance appraisals and career } \\
\text { development. } \\
>\text { Employee training and education } \\
\text { provided. }\end{array}$ & $\begin{array}{l}\text { Global Reporting } \\
(2013)-6 \text { indicators }\end{array}$ \\
\hline $\begin{array}{l}\text { 9. Measurement, } \\
\text { planning and control }\end{array}$ & $\begin{array}{l}>\text { Strategic analyses of opportunities } \\
\text { and risks. } \\
>\quad \text { Set goals for planning and control } \\
\text { results. }\end{array}$ & $\begin{array}{l}\text { Global Reporting Initiative } \\
(2013)-5 \text { indicators } \\
\text { Lanz et al. (2014) - } 1 \text { indicator } \\
\text { Wang (2011) - } 1 \text { indicator }\end{array}$ \\
\hline 10. Improvement & $\begin{array}{l}>\text { Steadily improve the level of social } \\
\text { sustainability. } \\
>\text { Link to innovation management. }\end{array}$ & $\begin{array}{lr}\text { Global Reporting } \\
(2013)-4 \text { indicators }\end{array}$ \\
\hline 11. Communication & $\begin{array}{l}\text { True dialogue with stakeholders. } \\
\text { Transparency. } \\
\text { Periodic reporting; report regularly on } \\
\text { goals, measurements and } \\
\text { achievements. } \\
\text { Programs for adherence to laws } \\
\text { related to marketing communications, } \\
\text { advertising, promotion and } \\
\text { sponsorship. }\end{array}$ & $\begin{array}{l}\text { Global Reporting } \\
(2013)-2 \text { indicators }\end{array}$ \\
\hline
\end{tabular}

The next step was to develop survey items of CSS culture. The identified social sustainability dimensions were converted into survey items, partially based on an existing inventory of corporate culture statements that was developed by (Herrmann et al., 2004) and operated by Schönborn (2010) in a study of 2,873 respondents from more than 100 German-speaking enterprises to measure and analyze corporate culture. This previous inventory of corporate culture included 140 items assigned to the three levels of corporate culture; i) artifacts, ii) values and iii) assumptions. Eighty relevant items from that inventory were selected. After that, missing aspects of the established CSS culture dimensions were verbalized as 39 additional items. The items were verbalized for agreement on a Likert scale ranging from 1 (fully disagree) to 5 (fully agree). As an additional step of validation and refinement, a group of independent experts from European academia and industry were involved in a Delphi evaluation of the identified dimensions and items, and were asked to assess whether the collection of dimensions and items contained sufficiently concrete terms and conditions to obtain a picture of CSS culture in practice. 


\subsubsection{Corporate financial success}

In the German company poll, objective indicators were sought to categorize a company as successful or non-successful. The most generally used indicators to assess success found in previous studies were: turnover, growth of turnover, profit before tax (PBT), earnings before interest and taxes (EBIT), earnings before interest, taxes, depreciation and amortization (EBITDA), return on investment (ROI) and stock price. Moreover, according to Baetge et al. (2007), to guarantee comparability with other studies, the figures of "headcount", "turnover", "EBIT" or "EBITDA" are recommended for determination purposes and these should be consolidated for the last three financial years.

To select the most appropriate indicators to collect, an expert group was consulted. The expert group's evaluation led to the decision to survey 'growth of turnover' and EBIT as indicators of financial success of a company. Therefore, 'growth of turnover' and EBIT were obtained for the last three financial years via public balance sheets obtained through www.bundesanzeiger.de in 2014.

In the panel poll, a precondition for respondents to be selected for the panel was to be employed in a business enterprise, and they participated on condition of anonymity. Thus, their employer enterprises are not known explicitly because of the recruitment method. Their employer's success, therefore, needed to be gauged by supplementary questions in the questionnaire. Therefore, five items rating the overall performance of the company, as suggested by (Margolis, Elfenbein, \& Walsh, 2007), were added to the panel poll questionnaire:

1. Over the past 3 years we have achieved all our goals in full;

2. Many new jobs have been created in our unit over the past 3 years;

3. Our company has succeeded in increasing its sales volume substantially over the past 3 years;

4. Our company has succeeded in increasing its profits over the past 3 years;

5. Our company has succeeded in increasing its market share substantially over the past 3 years.

These items were also rated using a 5-point Likert scale ranging from 1 (strongly disagree) to 5 (strongly agree). 


\section{Analysis and Results}

\subsection{Factor analysis - Corporate Social Sustainability Culture dimensions}

Item analyses were performed based on all data points $(\mathrm{N}=1178)$. Based on exploratory factor analyses as well as theoretical considerations from the literature, Four aggregated corporate social sustainability culture dimensions were identified:

\section{Sustainability strategy and leadership}

Strategies of creating and "living" a sustainable culture, including measuring and improving respective processes, and making them into reality in the company, fostering openness, responsibility, trust, and respect, and the corresponding effort and dedication of the employees.

\section{Mission, communication and learning}

More cognitive and communicative aspects of sustainability, such as corporate learning, communication with the various stakeholders including those outside of the company, and integrity.

\section{Social care and work life}

Strategies emphasizing social behaviours within the company, such as reward systems, equal rights, and care and provision for the employees.

\section{Loyalty and identification}

This aspect concerns the employees' perspective, such as identification with and loyalty towards the company.

\subsection{Comparison analysis}

The total dataset $(\mathrm{N}=1178)$ was analyzed for its significance compared to the mean value and the level of agreement. 
For the Company data, the scaled and dichotomized variables were created by ratings based on the objective parameters of each company. For the panel data, we created a dichotomized version of company success by contrasting the lowest 25 percent with the highest 25 percent.

The comparison demonstrates that the mean manifestation of the value profile (mv) in successful companies (sc) is more intensely pronounced, compared to the mean manifestation of the values in non-successful companies (n-sc).

The differences of the $s c$ versus $n$-sc profiles were quite significant across all dimensions. This is demonstrated by both the difference in the mean value as well as the comparison of the dichotomized top / low values (level of agreement). Hence, Hypothesis H1 is confirmed.

The values of the difference in the profile $\mathrm{mv}(\mathrm{sc})$ and $\mathrm{mv}(\mathrm{n}-\mathrm{sc})$ are so large and so consistent that the profile comparison is a suitable characteristic for determining the success or non-success of the analyzed company. The presentation of the four dimensions of CSS culture based on European data indicates a highly consistent result. The four dimensions are significantly more pronounced in successful companies compared to non-successful companies. In terms of cultural characteristics, these measurable and hence identifiable differences in the culture of social sustainability are relevant enough to reliably differentiate between successful companies and non-successful companies. Hence, Hypothesis $\mathrm{H} 2$ is confirmed.

\subsection{Analysis of the Company poll}

\subsubsection{Multiple regression}

A regression analysis of the company data was performed with just the three independent variables "Mission, communication and learning", "Social care and work life", and "Loyalty and identification", while the dimension "Sustainability strategy and leadership" was held as constant. Table 4 shows a typical result.

TABLE 4

\section{Coefficients $^{a}$ (Regression 5)}

\section{Unstandardized \\ Coefficients}

Co-linearity

Statistics 


\begin{tabular}{lccccccc} 
& $\boldsymbol{B}$ & Std. Error & Beta & $\boldsymbol{t}$ & Sig. & Tolerance & VIF \\
\hline $\begin{array}{l}\text { (Constant) } \\
\begin{array}{l}\text { Mission, } \\
\text { communication \& }\end{array}\end{array}$ & 3.15 & 0.15 & & 21.07 & 0.00 & & \\
$\begin{array}{l}\text { learning } \\
\begin{array}{l}\text { Social care \& } \\
\text { work life }\end{array}\end{array}$ & 0.92 & 0.22 & 0.50 & 4.22 & 0.00 & 0.39 & 2.54 \\
$\begin{array}{l}\text { Loyalty \& } \\
\text { identification }\end{array}$ & -0.80 & 0.21 & 0.27 & 2.14 & 0.03 & 0.35 & 2.86 \\
\hline
\end{tabular}

a Dependent Variable: corporate financial success, objective scale

The variables "Mission, communication and learning" and "Loyalty identification" are highly significantly related to the dependent variable "corporate financial success", as is "Social care and work life".

\subsubsection{Discriminant analysis}

A discriminant analysis was performed based on the dichotomized success variable. It was found that all three predictor variables appear to relate significantly to the company's success. However, the variable "Loyalty and identification" relates negatively to the corporate financial success in this company sample. It may mean that "Loyalty and identification", as far as it is not related to "Sustainability strategy and leadership", may not directly foster the company's success or may be an attitude that too strongly clings to existing procedures.

\subsection{Analysis of the Panel poll}

\subsubsection{Multiple regression}

A series of multiple regression analyses were performed with the aim to identify the relations between the four aforementioned dimensions (predictor variables) and corporate financial success.

As in the company poll, it was found that both "Sustainability strategy and leadership" and "Mission, communication and learning" and are highly significant and positive predictors of corporate financial success. In interpreting the results, the 2 following assertions are made: first, the more a company pursues a strategy of sustainability leadership characterized by a controlled realization in several areas 
- such as learning, communication, openness, trust, and respect etc. - the higher the probability of classifying this company as successful. Second, "Loyalty and identification" of employees as well as "Social care and work life" for employees both relate to corporate success, but only to the extent that they result from a sustainability strategy leadership.

Hypothesis H4 was also confirmed: successful companies (sc) and non-successful companies (n-sc) differ from one another with regard to respective manifestations of of CSS culture values. The characteristics for success are pictured by the values from the dimensions "Sustainability strategy \& leadership" and "Mission, communication and learning"; i.e., these dimensions are the success-drivers. Overall, the results reported so far were basically the same when a discriminant analysis with the dichotomized company success variable was performed. In the case of the panel data, the discriminant function yielded $83,5 \%$ correct classifications; for the company poll, this function yielded $70,9 \%$ correct classifications. Regression calculations performed on different models could explain the variance of $44-46 \%$ (r2) for success by the characteristic profile of the four dimensions. Accordingly, it follows that the likelihood that a company belongs to the classification of success $(y=1)$ is $44-46 \%$, and can be explained with the effect of the profiles of CSS culture analyzed here.

\subsection{Analysis with all items}

In the final step, to examine whether any individual CSS culture items (beyond the four dimensions discussed above) could drive corporate financial success, a multiple regression analysis was performed incorporating all items. The intention of this analysis was to relate the findings of the study to more practical recommendations about what level - i.e., Individual, Industry and Society - provides an appropriate platform for different expressions of social sustainability culture, independently of the previous work with the four dimensions.

In a preparatory step, correlations were calculated for the 119 items with the dichotomized success factors. Items were selected based on statistical relevance. The additional regression analyses represent some confirmation of our results regarding the dimensions and provide an indication of common cultural attitudes into three stratified levels of action - i) Individual, ii) Industrial and iii) Societal. 
Table 5 shows the single predictors in three clusters as success-related driving forces of a social sustainability culture. These quantitatively measurable characteristics thus represent visible successrelated characteristics in companies.

TABLE 5

Clusters of CSS culture items at three levels of action: i) Individual, ii) Industry and iii) Society

\begin{tabular}{lll}
\hline \multicolumn{1}{c}{ Individual level } & \multicolumn{1}{c}{ Industrial level } & \multicolumn{1}{c}{ Societal level } \\
\hline $\begin{array}{l}\text { Consideration of personal } \\
\text { circumstances. }\end{array}$ & $\begin{array}{l}\text { Decisions geared to future } \\
\text { challenges. }\end{array}$ & $\begin{array}{l}\text { As much attention to social } \\
\text { factors as to economics. }\end{array}$ \\
\hline $\begin{array}{l}\text { Employees enjoy a good standard } \\
\text { of living. }\end{array}$ & $\begin{array}{l}\text { Employees show a high degree } \\
\text { of initiative. }\end{array}$ & $\begin{array}{l}\text { Attention paid to environmental } \\
\text { consequences }\end{array}$ \\
\hline $\begin{array}{l}\text { Employees are awarded something } \\
\text { "extra". }\end{array}$ & $\begin{array}{l}\text { Encourage participation of } \\
\text { employees. }\end{array}$ & $\begin{array}{l}\text { Contributions to the local } \\
\text { community. }\end{array}$ \\
\hline $\begin{array}{l}\text { Good performance is suitably } \\
\text { rewarded. }\end{array}$ & $\begin{array}{l}\text { Goals compared with } \\
\text { measurable indicators. }\end{array}$ & $\begin{array}{l}\text { Good constant communication to } \\
\text { stakeholders. }\end{array}$ \\
\hline $\begin{array}{l}\text { Good prospects of employees } \\
\text { developing. }\end{array}$ & $\begin{array}{l}\text { Communications meet ethical } \\
\text { requirement. }\end{array}$ & $\begin{array}{l}\text { Involve regional business } \\
\text { partners. }\end{array}$ \\
\hline $\begin{array}{l}\text { Good work-life balance. } \\
\text { Great importance of training. }\end{array}$ & $\begin{array}{l}\text { Sustainability mission is } \\
\text { ambitious. }\end{array}$ \\
\hline $\begin{array}{l}\text { Provided work is both interesting } \\
\text { and varied. }\end{array}$ & $\begin{array}{l}\text { Measurable goals for } \\
\text { achievement of results. }\end{array}$ & $\begin{array}{l}\text { Sustainability viewed as growth } \\
\text { opportunity. }\end{array}$ \\
\hline Superiors always treat fairly. & $\begin{array}{l}\text { Members of the team } \\
\text { complement one another. }\end{array}$ & \\
\hline $\begin{array}{l}\text { Support for personal } \\
\text { circumstances. }\end{array}$ & $\begin{array}{l}\text { Mission statement aligned with } \\
\text { corporate social sustain-ability. }\end{array}$ & \\
\hline $\begin{array}{l}\text { The performance of each person is } \\
\text { respected equally. }\end{array}$ & $\begin{array}{l}\text { Practices conform to moral } \\
\text { principles. }\end{array}$ & \\
\hline Trust in integrity of superiors. & Recognize workers' rights. & \\
\hline $\begin{array}{l}\text { Consideration of personal } \\
\text { circumstances. }\end{array}$ & $\begin{array}{l}\text { Social risks as important as } \\
\text { corporate risks. }\end{array}$ & \\
\hline & $\begin{array}{l}\text { Sustainable products/ services } \\
\text { are corporate strategy. }\end{array}$ & \\
\hline & &
\end{tabular}

\section{Discussion and conclusions}

Managing social sustainability is gaining importance in politics, society and the economy as a fundamental approach for dealing with the global challenges of the future (Sachs, 2012). Management now increasingly pay attention to how companies can align the requirements of social sustainability with those of competitiveness. In this respect, the basic hypothesis of the present study that CSS culture is positively correlated to the financial success of a company has been proven. Moreover, the results of the statistical analysis show four dimensions of CSS culture - "Sustainability strategy and 
leadership", "Mission, Communication and Learning", "Social care and work life" and "Loyalty and identification" - as predictors that differentiate between successful and non-successful companies. In the following paragraphs, the main contributions to theory and implications for managers are crystallized. Finally, the main limitations of this research are pointed out as well as proposals for follow-up investigations.

First, our results contribute to the literature by shedding new light on aggregated as well as particular manifestations of CSS culture, something which has been largely overlooked by the literature on social sustainability and CSR so far (e.g., Docherty et al., 2008; Maon et al., 2010). In doing so, it may be regarded as a follow-up to the efforts of Spangenberg and Omann (2006), although with a more detailed elaboration of criteria/dimensions for social sustainability, and also with a corporate rather than a policy perspective. Moreover, our results contribute to enrich our current knowledge by providing evidence of the positive effects of CSS culture - and its dimensions - on corporate success, which has been argued mainly qualitatively and only seldom tested empirically (e.g., Perrini et al., 2011). Figure 1 summarizes the hierarchical/sequential relationship that was found between the four dimensions of CSS culture and the likelihood of corporate financial success. 
Figure 1: Four dimensions - Impact on corporate financial success

Social Sustainability: Key Performance Indicators (KPIs)

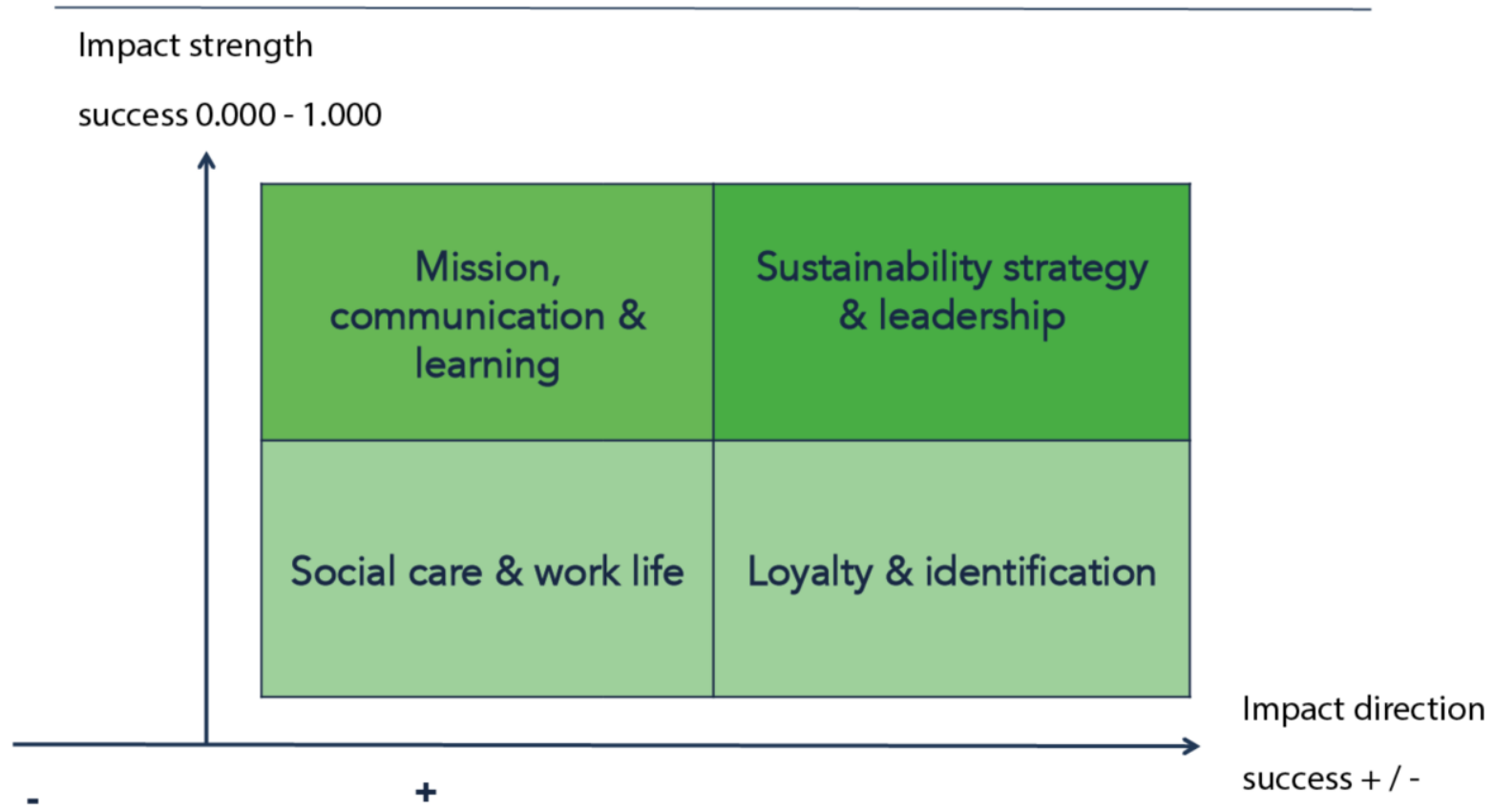

"Sustainability strategy and leadership" is highly positively related to corporate financial success, and "Mission, communication and learning" is highly related to company success as well, even though they are based on different factors. This suggests that a systematically performed corporate sustainability strategy and leadership - which is characterized by openness, responsibility, participation of employees, mutual trust and respect, and emphasis on learning and communicationare positively related to corporate financial success. This finding aligns well with previous studies suggesting that a strategic approach to CSR and sustainability, according to which CSR and sustainability engagement initiatives are closely linked and consistent to the company's strategy, have a positive impact on company performance (e.g. Boesso, Favotto \& Michelon, 2015).

In contrast, aspects of "Social care and work life", such as reward systems, equal rights, care and provision of the company, are only related to corporate financial success as far as these aspects coincide with an established sustainability leadership strategy. In fact, these aspects should follow after a sustainability leadership strategy. On the other hand, when reward systems, equal rights, care and provision appear but are not related to a sustainability leadership strategy, they do not seem to conclusively lead to corporate financial success. Therefore, these aspects of employee orientation - 
consistently viewed with the strategic fit-perspective on human resource management (Schuler \& Jackson, 1987) - only have an effect on success if they are anchored within a sustainability strategy leadership. Moreover, according to Guerci \& Pedrini (2014), consensus between human resource and sustainability management is essential to send employees coherent messages about their key role as recipients and actors of social sustainability who contribute to the success of the organization.

Similarly, "Loyalty and identification" of the employees with their company is another significant (and positive) predictor of corporate financial success in the panel data. In contrast, in the German companies' data, the relationship is significant but negative. This might hint about cultural peculiarities in Germany; specifically, "Loyalty and identification" seems not to have a positive impact on corporate financial success if detached from a sustainability strategy leadership of the company. For example, "excessive" harmony might have a positive impact on employee attitudes but not directly on corporate financial performance.

Overall, the findings of our research, in line with the strategic CSR and sustainability perspective (e.g. Baumgartner, 2014), provide support to the argument that companies, who reap the most benefits of social sustainability, do not consider it as pertaining to an isolated initiative or an add-on to their business, but they embrace social sustainability with conviction, embed it in their core values and way of doing business - especially in their strategy and leadership - and manage it in a competent way. Consistently with the theoretical description of the "cultural embedment phase" proposed by Maon et al. (2010), those companies have greater awareness of employees' and external stakeholders' needs, translate those needs into a social sustainability value-creation strategy, and re-orient decisions, activities and systems of the company at all levels to contribute to the social sustainability strategy.

The findings of this research have also significant implications for managers, corporate change agents and policy makers interested in embedding social sustainability in corporate culture. The examined and validated dimensions of CSS culture also represent a good contribution towards "best practices" for supporting socially sustainable companies. Based on the correlation of success established, "Sustainability strategy and leadership", "Mission, communication and learning", "Social care and work life", "Loyalty and identification" are therefore suggested as Key Performance Indicators (KPIs) 
of social sustainability. The measurement of social sustainability can be provided as a requirement for planning and for guiding change processes within the company. It follows from this that the planning and implementation of social sustainability ought to gain significance for managers.

Our findings should be interpreted considering the limitations that our study has. First, the items that were selected for the analyses were based on previous efforts in literature regarding corporate culture (in particular Schönborn, 2010), but their validity to the manufacturing context had not been assessed prior to the study (with the exception of the consultation of the expert group, who were also tasked with evaluating other aspects of the items). As described, we conducted an item analysis assessing dimensionality, consistency, and item-total-correlations, but assessing construct validity and reliability would require a further step that is more appropriate for a follow-up study.

Second, the factors that entered the study are still somewhat dependent on each other. It may be possible that there is an underlying single factor of sustainability explaining most of the variance of success/failure of a company. Further analyses of a more specialized, purposive nature may be necessary to investigate this, especially in order to determine the role played by differences across nations and industrial sectors.

Third, the idea to include objective, publicly reported data to assess financial success or failure of the companies seems sensible; these data may be used to validate the success ratings assessed by the panel participants, in a follow-up study.

Fourth, future studies covering more countries both in Europe (such as the newer so-called EU13 countries, which are primarily eastern European) and worldwide (such as the US, Mexico, China, India, etc.) would be useful to highlight similarities and differences, and to strengthen the generalizability of results across geographical areas.

Another point to consider is that in the current study, the success or not of a company is identified by looking at a snapshot of the company's economic performance during the previous three years. Further research is needed to be able to evaluate the impact of social sustainability practices in newer, developing companies (like start-ups), where although the economic results may be low, the company may very well be successful and innovative, looking forward to a rather promising future. Similar 
issues may apply to companies undergoing strategic restructuring, or following aggressive investments which may provide economic benefits in the long-term, although not immediately. These companies may respect social sustainability dimensions and values, but their economic performance may not yet be apparent, or vice versa. Therefore, while in the current work we are looking at the current situation regarding both economic performance and social sustainability, it could be valuable to investigate currently financially successful companies regarding their social sustainability practices when they were at their beginning. This would also provide a hint as to whether social sustainability is a priority that new companies should leverage early to become successful.

In relation to the previous thoughts, a question raised during the course of this work was whether social sustainability is a driver for corporate financial success, or an outcome of success. This query certainly merits a more detailed investigation. In light of the previous literature, it could be argued that CSS culture is both a driver and an outcome of success; however, our study's results suggest that specific tangible elements of CSS culture may very well be an antecedent to financial success.

In conclusion, despite the limitations this study - as any study - has, it advances our detailed knowledge on CSS culture and its components, as well as its relationship with financial success. It elaborates specific, performance-influencing dimensions of CSS culture, and examines the interrelationship between them and their influence on corporate success. In doing so, it provides evidence-grounded recommendations to managers and change agents willing to integrate social sustainability in their corporate culture to ultimately improve their company's performance.

\section{Acknowledgements}

We gratefully acknowledge the financial support of the EU $7^{\mathrm{TH}}$ framework programme, FP7/20072013 that has funded this research under grant agreement no. 608734. We also want to warmly thank our expert evaluation panel for their contributions within their areas of expertise to the SO SMART project: Luciano Pero, Mari Kira, Ralf Frank and Raija Hämäläinen.

\section{References}


Backhaus, K., Erichson, B., Plinke, W., \& Weiber, R. 2000. Multivariate Analysemethoden: Springer.

Baetge, J., Schewe, G., Schulz, R., \& Solmecke, H. 2007. Unternehmenskultur und Unternehmenserfolg: Stand der empirischen Forschung und Konsequenzen für die Entwicklung eines Messkonzeptes. Journal für Betriebswirtschaft, 57(3-4): 183-219.

Barker, B., Ingersoll, L., \& Teal, G. 2014. Understanding CSR culture and subcultures: Consensual and conflicting narratives. International Journal of Employment Studies, 22(2): 25.

Baumgartner, R. J., 2014. Managing corporate sustainability and CSR: A conceptual framework combining values, strategies and instruments contributing to sustainable development. Corporate Social Responsibility and Environmental Management, 21(5), 258-271.

Berlin, C., Barletta, I., Fantini, P., Georgoulias, K., Hanisch, C., Lanz, M., Latokartano, J., Pinzone, M., Schönborn, G., Stahre, J., Taisch, M., Tuokko, R. 2016. Prerequisites and conditions for socially sustainable manufacturing in Europe's future factories - results overview from the SO SMART project.Proceedings of the 7th International Conference on Applied Human Factors and Ergonomics AHFE 2016, Walt Disney, Florida, USA: 319-331.

Boesso, G., Favotto, F., \& Michelon, G. 2015. Stakeholder prioritization, strategic corporate social responsibility and company performance: further evidence. Corporate Social Responsibility and Environmental Management, 22(6), 424-440.

Boyce, A. S., Nieminen, L. R., Gillespie, M. A., Ryan, A. M., \& Denison, D. R. 2015. Which comes first, organizational culture or performance? A longitudinal study of causal priority with automobile dealerships. Journal of Organizational Behavior, 36(3): 339-359.

Calabrese, A., Costa, R., Menichini, T., Rosati, F., \& Sanfelice, G. 2013. Turning Corporate Social Responsibility-driven Opportunities in Competitive Advantages: a Two-dimensional Model. Knowledge and Process Management, 20(1): 50-58.

Calvano, L. 2013. Tug of war: Caring for our elders while remaining productive at work. The Academy of Management Perspectives, 27(3): 204-218.

Chand, M. \& Tung, R. L. 2014. The aging of the world's population and its effects on global business. The Academy of Management Perspectives, 28(4): 409-429.

Cole, D.C., Wells, R.P., Frazer, M.B., Kerr, M.S., Neumann, W.P., Laing, A.C. and Ergonomic Intervention Evaluation Research Group, 2003. Methodological issues in evaluating workplace interventions to reduce work-related musculoskeletal disorders through mechanical exposure reduction. Scandinavian journal of work, environment \& health, 29(5): 396-405.

Cottyn, J., Van Landeghem, H., Stockman, K. \& Derammalaere, S. 2011. A method to align a manufacturing execution sytem with lean objectives. International Journal of Production

Research, 49(14): 4397-4413.

Denison, D., Nieminen, L., \& Kotrba, L., 2014. Diagnosing organizational cultures: A conceptual and empirical review of culture effectiveness surveys, European Journal of Work and Organizational Psychology, 23:1, 145-161, DOI: 10.1080/1359432X.2012.713173

Destatis. 2014. Sustainable Development in Germany - Indicator Report 2014.

Docherty, P., Kira, M., \& Shani, A. R. 2008. Creating sustainable work systems: Developing social sustainability: Routledge. 
Duarte, F. 2010. Working with corporate social responsibility in Brazilian companies: The role of managers' values in the maintenance of CSR cultures. Journal of Business Ethics, 96(3): 355-368.

Eccles, R. G., Perkins, K. M., \& Serafeim, G. 2012. How to become a sustainable company. MIT Sloan Management Review, 53(4): 43.

Elkington, J. 1997. Cannibals with forks. The triple bottom line of 21st century.

Enz, C. A. 1986. Power and shared values in the corporate culture.

Epstein, M. J. \& Buhovac, A. R. 2014. Making sustainability work: Best practices in managing and measuring corporate social, environmental, and economic impacts: Berrett-Koehler Publishers.

Epstein, M. J., Buhovac, A. R., \& Yuthas, K., 2015. Managing social, environmental and financial performance simultaneously. Long Range Planning, 48(1), 35-45.

Galbreath, J. 2010. Drivers of corporate social responsibility: The role of formal strategic planning and firm culture. British Journal of Management, 21(2): 511-525.

Garz, H. \& Schnella, F. F. 2010. KPIs for ESG. A Guideline for the Integration of ESG into Financial Analysis and Corporate Validation. Version 3.0, Frankfurt, DVFA/EFFAS.

Geissdoerfer, Martin, Doroteya Vladimirova, \& Steve Evans, 2018. Sustainable business model innovation: A review, Journal of Cleaner Production. https://doi.org/10.1016/j.jclepro.2018.06.240

George, G., Haas, M. R., \& Pentland, A. 2014. Big data and management. Academy of Management Journal, 57(2): 321-326.

Glavas, A., 2016. Corporate social responsibility and organizational psychology: An integrative review. Frontiers in psychology, 7, 144.

Global Reporting Initiative, 2013. G4 sustainability reporting guidelines, Global Reporting Initiative: Amsterdam.

Griffin, J. J. \& Mahon, J. F. 1997. The corporate social performance and corporate financial performance debate twenty-five years of incomparable research. Business \& Society, 36(1): 5-31.

Guerci, M. \& Pedrini, M. 2014. The consensus between Italian HR and sustainability managers on HR management for sustainability-driven change-towards a 'strong' HR management system. The International Journal of Human Resource Management, 25(13), 1787-1814.

Hatch, M. J. 2011. Material and meaning in the dynamics of organizational culture and identity with implications for the leadership of organizational change. Handbook of Organizational Culture and Climate, 2nd edition. Thousand Oaks, CA: Sage: 341-358.

Herrmann, A., Peetz, S., \& Schönborn, G. 2004. Werte führen zum Erfolg. Personal, 9: 30-34.

Hollensbe, E., Wookey, C., Hickey, L., George, G., \& Nichols, C. V. 2014. Organizations with purpose. Academy of Management Journal, 57(5): 1227-1234.

Husted, B. W. \& Allen, D. B. 2011. Corporate social strategy: Cambridge University Press.

Jones, D. A., Willness, C. R., \& Madey, S. 2014. Why are job seekers attracted by corporate social performance? Experimental and field tests of three signal-based mechanisms. Academy of Management Journal, 57(2): 383-404.

Kiron, D., Kruschwitz, N., Rubel, H., Reeves, M., \& Fuisz-Kehrbach, S.-K. 2013. Sustainability's 
next frontier: Walking the talk on the sustainability issues that matter most. MIT Sloan Management Review Research Report.

Kulik, C. T., Ryan, S., Harper, S., \& George, G. 2014. Aging populations and management. Academy of Management Journal, 57(4): 929-935.

ISO 22400-2. 2014. Automation systems and integration-key performance indicators (KPIs) for manufacturing operations management-part 2: definitions and descriptions. Geneva: International Standard Organization (ISO).

Lanz, M., Järvenpää, E., Nylund, H., Tuokko, R., Torvinen, S., \& Georgoulias, K. 2014. Sustainability and performance indicators landscape. In Proceedings of the 24th International Conference on Flexible Automation and Intelligent Manufacturing, San Antonio, TX, USA: 2023.

Linnenluecke, M. K. \& Griffiths, A. 2010. Corporate sustainability and organizational culture. Journal of world business, 45(4): 357-366.

Lo, K. Y., \& Kwan, C. L. 2017. The effect of environmental, social, governance and sustainability initiatives on stock value-Examining market response to initiatives undertaken by listed companies. Corporate Social Responsibility and Environmental Management, 24(6), 606-619.

Longoni, A., \& Cagliano, R. 2015. Environmental and social sustainability priorities. International Journal of Operations \& Production Management, 35(2), 216-245.

Maon, F., Lindgreen, A., \& Swaen, V. 2010. Organizational stages and cultural phases: A critical review and a consolidative model of corporate social responsibility development. International Journal of Management Reviews, 12(1): 20-38.

Margolis, J. D. \& Walsh, J. P. 2001. People and profits?: The search for a link between a company's social and financial performance: Psychology Press.

Margolis, J. D., Elfenbein, H. A., \& Walsh, J. P. 2007. Does it pay to be good? A meta-analysis and redirection of research on the relationship between corporate social and financial performance. Ann Arbor, 1001: 48109-41234.

Marshall, D., McCarthy, L., McGrath, P., \& Claudy, M. 2015. Going above and beyond: how sustainability culture and entrepreneurial orientation drive social sustainability supply chain practice adoption. Supply Chain Management: An International Journal, 20(4): 434-454.

Mejabi, O. O. 2003. Framework for a lean manufacturing planning system. International Journal of Manufacturing Technology and Management, 5(5-6):563-578.

Orlitzky, M., Schmidt, F. L., \& Rynes, S. L. 2003. Corporate social and financial performance: A meta-analysis. Organization studies, 24(3): 403-441.

Perrini, F., Russo, A., Tencati, A., \& Vurro, C., 2011. Deconstructing the relationship between corporate social and financial performance. Journal of Business Ethics, 102(1), 59-76.

Pfeffer, J. 2010. Building sustainable organizations: The human factor. The Academy of Management Perspectives, 24(1): 34-45.

Pinzone, M., Barletta, I., Berlin, C., Albè, F., Orlandelli, D., Johansson, B., Taisch, M., 2018. A framework for operative and social sustainability functionalities in Human-Centric Cyber-Physical Production Systems, Computers \& Industrial Engineering, doi: https://doi.org/10.1016/j.cie.2018.03.028 
Porter, M. E. \& Kramer, M. R. 2011. The big idea: Creating shared value. Harvard Business Review, 89(1): 2 .

Sachs, J. D. 2012. From millennium development goals to sustainable development goals. The Lancet, 379(9832): 2206-2211.

Sackmann, S. A. 2002. Unternehmenskultur: Analysieren-Entwickeln-Verändern. Neuwied: Luchterhand.

Sackmann, S. A. \& Stiftung, B. 2006. Success factor: Corporate culture. Developing a Corporate Culture for High Performance and Long-term Competitiveness, Six Best Practices. Kinndle Edition.

Sackmann, S. A. 2007. Methoden zur Erfassung von Unternehmenskultur. Ansätze zur Messung von Unternehmenskultur. Möglichkeiten, Einordnung und Konsequenzen für ein neues Instrument. Rostock: 6-25.

Sackmann, S. A. 2011. Culture and performance. The handbook of organizational culture and climate, 2: 188-224.

Schaltegger, S. \& Burritt, R. 2018. Business Cases and Corporate Engagement with Sustainability: Differentiating Ethical Motivations. Journal of Business Ethics DOI: 147: 241. https://doi.org/10.1007/s10551-015-2938-0

Schein, E. H. 1984. Coming to a new awareness of organizational culture. Sloan management review, 25(2): 3 .

Schein, E. H. 1990. Organizational culture: American Psychological Association.

Schein, E. H. 2009. The corporate culture survival guide: John Wiley \& Sons.

Schein, E. H. 2010. Organizational culture and leadership: John Wiley \& Sons.

Schönborn, G. 2010. Value performance: On the relation between corporate culture and corporate success. Zeitschrift für Psychologie/Journal of Psychology, 218: 234-242.

Schönborn, G. 2014. Unternehmenskultur als Erfolgsfaktor der Corporate Identity: die Bedeutung der Unternehmenskultur für den ökonomischen Erfolg von Unternehmen: Springer-Verlag.

Schrempf-Stirling, J., Palazzo, G., \& Phillips, R. 2015. Historic corporate social responsibility. Academy of Management Review: amr. 2014.0137.

Schuler, R. S., \& Jackson, S. E. 1987. Linking competitive strategies with human resource management practices. Academy of Management Perspectives, 1(3), 207-219.

Sean, S. H. A. R. C. \& Saliba, M. M. M. 2016. A relationship between corporate sustainability and organizational change (Part One). Industrial and Commercial Training, 48(1): 16-23.

Searcy, C., Dixon, S. M., \& Neumann, W. P. (2016). The use of work environment performance indicators in corporate social responsibility reporting. Journal of Cleaner Production, 112, 29072921.

Spangenberg, J.H., Omann, I. 2006. Assessing social sustainability: social sustainability and its multicriteria assessment in a sustainability scenario for Germany. International Journal of Innovation and Sustainable Development, 1(4): 318-348.

UN Global Compact, 2014. Overview of the UN Global Compact, https://www.unglobalcompact.org/ParticipantsAndStakeholders/business_associations.html 
Unver, H. O. 2013. An ISA-95-based manufacturing intelligence system in support of lean initiatives. The International Journal of Advanced Manufacturing Technology, 65(5-8), 853-866.

van der Wiele, T., Kok, P., McKenna, R., \& Brown, A. 2001. A corporate social responsibility audit within a quality management framework. Journal of Business Ethics, 31(4): 285-297.

Wang, J. X. 2011. Lean Manufacturing - Business Bottom-Line Based. CRC Press. 257.

Weerts, K., Vermeulen, W., Witjes, S., 2018. On Corporate Sustainability Integration: Analysing Corporate Leaders' Experiences and Academic Learnings from an Organisational Culture Perspective, Journal of Cleaner Production, doi: 10.1016/j.jclepro.2018.07.173

Wood, D. J. 2010. Measuring corporate social performance: A review. International Journal of Management Reviews, 12(1): 50-84. 